\title{
Development and evaluation of iron-rich meatloaves containing pork liver for schoolchildren
}

\author{
Silvana Mariana SREBERNICH ${ }^{1 \star}$, Expedito Tadeu Facco SILVEIRA ${ }^{2}$ in memorian, Gisele Mara Silva \\ GONÇALVES 3 , Rita de Cássia Salvucci Celeste ORMENESE², Marcelo Antonio MORGANO²
}

\begin{abstract}
Iron deficiency is a highly prevalent nutritional problem worldwide and it impacts on the cognitive development of children. Therefore, the aim of this research was to develop meatloaf with high iron content by using in their formulations pork liver. Meatloaves were prepared with additions of 9.98\% and 13.31\% (formulations A and B) of pork liver in order to meet 15\% and 20\% of the daily requirement of iron $(10 \mathrm{mg} /$ day $)$ for children. Samples were evaluated regarding their physicochemical, microbiological and sensory characteristics. The results were subjected to Analysis of Variance (ANOVA) followed by Tukey test. Results of physicochemical analyses showed an increase in protein and mineral contents and a decrease in fat content. The iron and zinc contents were respectively $100.0 \%$ and $70.83 \%$ (formulation A) and $152.73 \%$ and $97.92 \%$ (formulation B) higher than that of the standard formulation. Regarding fat content, the reduction of $31.5 \%$ in formulation B makes it a light product. As for the microbiological aspect, all meatloaves were adequate for consumption. Regarding sensory analysis, all the attributes considered were not statistically different, but for purchase intention test formulation B was better accepted. Therefore, formulations $\mathrm{A}$ and $\mathrm{B}$ are good sources of iron and zinc.
\end{abstract}

Keywords: mineral composition; sensory analyses; anemia control; school meals.

Pratical Application: Development of meatloaves with addition of pork liver as a source o iron for the control of anemia.

\section{Introduction}

Iron deficiency is the most common and most widely distributed nutritional deficiency in the world, affecting nearly $20 \%$ of the world population. In Latin America, anemia is estimated to affect $30 \%$ of preschool children. According to recent data, the prevalence of anemia in Brazilian children and women in Brazil is $20.9 \%$ and $29.4 \%$ respectively, with the Northeastern region showing the highest prevalence rates of anemia among children (25.5\%) and women (39.1\%) (Brasil, 2009).

Data from the World Health Organization show that 2.15 million preschool children are at risk for iron deficiency, which represents a highly relevant problem not only in developing countries but also in industrialized countries (McClung \& Karl, 2009). The more severe the iron deficiency anemia in preschool children, the higher the chance of delay in motor and mental development, with consequences in the future intellectual development of the child (Lynch, 2005).

International organizations point out to three strategies for the prevention of anemia: nutritional education, food fortification, and iron supplementation. Food fortification is worldwide considered as the most practical method and the one that provides the best cost-benefit ratio, especially in regions where this nutritional deficiency is highly prevalent (Beinner \& Lamounier, 2003; Lynch, 2005), with the main advantage of reaching all segments of the population and not requiring individual's cooperation.

However, iron fortification is more difficult than other micronutrients because the highly soluble forms of iron, such as ferrous sulfate ( $\mathrm{FeSO} 4$ ), are chemically reactive and produces undesirable sensory changes when added to food (Cook \& Reusser, 1983), in addition to causing negative side effects such as inhibition of the immune system and increased risk for infectious diseases (Muñoz et al., 2007), and even growth impairment (Idjradinata et al., 1994; Lind et al., 2008). Other drawbacks attributed to ferrous sulfate are the lack of regular supply and the negative effect caused by the excess of this element, which can lead to the growth of opportunistic microorganisms in the intestine. Conversely, compounds containing inert iron or insoluble iron salts, such as reduced iron and ferrous phosphate, do not produce these changes, but have low absorption rates. Nevertheless, the use of pharmacological supplements is not adequate for the consolidation of healthy eating habits (Assis et al., 2004). As far as bioavailability is concerned, iron is the most difficult mineral to be added to food. Compounds with higher bioavailability are those that cause greater sensory changes to the product. Another great barrier for its use results from the fact that other components of the diet have an inhibitory role in iron absorption (Hurrell, 2002). 
The main causes of iron deficiency anemia are insufficient iron intake, particularly of heme iron, due to the low intake of foods of animal origin or to the low bioavailability of the iron consumed. Thus, the consumption of meat products becomes an alternative for the prevention and control of iron deficiency in children, in addition to allowing for the development of a menu richer in nutrients, especially in animal protein. Within this context, the use of pork meat products would be an alternative to be considered, due to the fact that pork meat is highly palatable (i.e., has a pleasant taste and flavor) and contains protein of high biological value (19 to 23\%), monounsaturated fatty acids, as well as high levels of iron, zinc, selenium, and potassium and low levels of cholesterol compared to meat from other species (poultry and bovine animals). Furthermore, it is an excellent source of B-complex vitamins, especially thiamine and riboflavin, and increases the absorption of non-heme iron when the diet has at least $50 \mathrm{~g}$ of pork meat (Bach Kristensen et al., 2005; Baech et al., 2003).

Therefore, the present study aimed to obtain and perform a physicochemical, microbiological and sensory evaluation of iron-rich meat loaves containing pork meat and pork liver, the latter of which is a low cost meat by-product that has high iron content.

\section{Materials and methods}

Two formulations of meatloaf (A and B) were developed, with the purpose of complying with $15 \%$ and $20 \%$, respectively, of the daily recommendation of iron intake $(10 \mathrm{mg} /$ day $)$ proposed by the Institute of Medicine (Institute of Medicine, 2002) for schoolchildren (Table 1).

\subsection{Preparation of the meatloaf}

Meatloaves were prepared according to the formulations shown in Table 1 and processed according to the flow chart presented in Figure 1.

\subsection{Preparation of the samples for analysis.}

After leaving the oven the cakes were cooled $\left(0^{\circ} \mathrm{C}-4^{\circ} \mathrm{C}\right)$, vacuum packaged and stored in freezing condition $\left(-18^{\circ} \mathrm{C}\right)$. On the day before carrying out the analysis, the samples were thawed under refrigerated condition. After thawing the samples, they were taken from each cake three slices being one of the central portion and two at approximately $1 / 4$ of each end (by the way, the cakes were baked in rectangular shape similar to those of commercial cakes). These three slices represented the sample of that cake.

\subsection{Physicochemical determination}

After meatloaves were prepared, $\mathrm{pH}$ (Instituto Adolfo Lutz, 2008) and the levels of lipids, moisture, mineral matter, protein and mineral elements (Horwitz, 2010) for each formulation were determined.

\subsection{Microbiological analysis}

Microbiological analysis of Salmonella sp., S. aureus, thermotolerant coliforms, E. coli, molds, yeasts, and Clostridium sulphite reducer $\left(46^{\circ} \mathrm{C}\right)$ were analyzed according to the methods described by Silva et al. (2010) in order to investigate whether the samples were in accordance with the microbiological standards established by Resolution No.12/01 of the Brazilian National Health Surveillance Agency (Agência Nacional de Vigilângia Sanitária, ANVISA) from the Ministry of Health, published on January 10, 2001 (Brasil, 2001).

Table 1. Amounts of the ingredients used in the two formulations of meatloaf.

\begin{tabular}{cccc}
\hline Ingredients & \multicolumn{3}{c}{ Formulation $^{*}$} \\
\cline { 2 - 4 }$(\mathrm{g} / 100 \mathrm{~g})$ & Standard & $\mathrm{A}$ & $\mathrm{B}$ \\
\hline Pork meat & 77.00 & 67.02 & 63.69 \\
Costolumbar bacon & 10.00 & 10.00 & 10.00 \\
Pork liver & 0.00 & 9.98 & 13.31 \\
Water & 10.00 & 10.00 & 10.00 \\
Salt & 1.40 & 1.40 & 1.40 \\
Erythorbate & 0.25 & 0.25 & 0.25 \\
Fosfate & 0.25 & 0.25 & 0.25 \\
Nitrite & 0.25 & 0.25 & 0.25 \\
Condiments & 0.85 & 0.85 & 0.85 \\
Total & 100.00 & 100.00 & 100.00 \\
\hline
\end{tabular}

${ }^{\star}$ Formulations A and B aim to comply with $15 \%$ to $20 \%$ of daily iron needs $(10 \mathrm{mg} /$ day) for $50 \mathrm{~g}$ of product, assumed daily consumption per child.

Pork meat, liver and bacon

$\downarrow$

Trituration $\leftarrow$ Remaining ingredients

(cutter)

$\downarrow$

Dough

$\downarrow$

Pouring the dough into a mold

$\downarrow$

Heat treatment at $160^{\circ} \mathrm{C} / 90 \mathrm{~min}$

$\downarrow$

Cooling $\left(0^{\circ} \mathrm{C}\right.$ to $\left.4^{\circ} \mathrm{C}\right)$

$\downarrow$

Vacuum packing

$\downarrow$

Storage at $-18^{\circ} \mathrm{C}$

Figure 1. Flow chart of the process of meatloaf preparation. 


\subsection{Sensory analysis}

The acceptance of the samples was assessed considering the following buying attributes: appearance, color, odor, flavor, and texture and using a structured nine-point mixed scale ranging from "1-Disliked it extremely" to "9-Liked it extremely", and purchase intention was assessed using a five-point scale ranging from "Definitely would buy it" and "Definitely would not it buy" (Figure 2).
Samples intended for sensory analysis were stored at $-18^{\circ} \mathrm{C}$ and were defrosted under refrigeration on the day before the performance of the sensory test. After being heated in water bath at the optimal temperature for consumption, samples randomly codified with three digits were served on disposable white dishes at a sensory evaluation room with individual booths under white lighting (equivalent to daylight) to a group of 60 untrained tasters, who were informed that it was a product

\section{SENSORY EVALUATION CHART}

Taster no.

date:

You are receiving two codified samples of meatloaf. Please taste both of them and then note down how much you LIKED or DISLIKED each sample in terms of appearance, color, smell, flavor, and texture using the scale below:

$$
\begin{aligned}
& 9 \text { - Liked it extremely } \\
& 8 \text { - Liked it very much } \\
& 7 \text { - Liked it moderately } \\
& 6 \text { - Liked it slightly } \\
& 5 \text { - Neither liked nor disliked it } \\
& 4 \text { - Disliked it slightly } \\
& 3 \text { - Disliked it moderately } \\
& 2 \text { - Disliked it very much } \\
& \text { 1- Disliked it extremely }
\end{aligned}
$$

How do you evaluate both samples with regard to the following aspects?

$\begin{array}{llll}\text { Sample } & & \text { Sample } & - \\ \text { Appearance } & - & \text { Appearance } & - \\ \text { Color } & - & \text { Color } & - \\ \text { Smell } & - & \text { Smell } & - \\ \text { Flavor } & - & \text { Flavor } & - \\ \text { Texture } & - & \text { Texture } & \end{array}$

Please comment on the samples evaluated:

Leaving aside the issue of price, when it comes to buying the products, what would you do?

\begin{tabular}{lll}
\multicolumn{2}{c}{ Sample } & \multicolumn{2}{c}{ Sample } \\
Purchase intention: & $($ ) & $($ ) \\
Definitely would buy it & $($ ) & $($ ) \\
Probably would buy it & $($ ) & $($ ) \\
Might or might not buy it & $($ ) & $($ ) \\
Probably would not buy it & $($ )
\end{tabular}

Figure 2. Sensory evaluation chart used to assess acceptance and purchase intention for the meatloaf. 
containing pork liver. Tests were carried out with volunteer consumers selected by invitation after they signed a written Free Consent Form. In addition, this study was approved by the Research Ethics Committee of Pontificia Universidade Católica de Campinas under protocol 882/09. The result of the evaluation was recorded on the Sensory Evaluation Chart.

\subsection{Statistical analysis}

Results for chemical, physicochemical, microbiological and sensory analyses of meatloaves were subjected to Analysis of Variance (ANOVA) followed by Tukey test for the comparison of means at a $5 \%$ probability level $(\mathrm{p}<0.05)$ (Statsoft, 2000).

\section{Results}

Table 2 shows the results for the determination of $\mathrm{pH}$ and proximate composition of meatloaves prepared with the standard formulation and with formulations A and B. Table 3 shows the results for the determination of mineral elements in meatloaves. Table 4 shows the results for acceptance test of meatloaves prepared with formulations A and B. Figure 3 shows the results for purchase intention of meatloaves.

\section{Discussion}

Although being very close, $\mathrm{pH}$ values of the three formulations showed significant difference $(\mathrm{p}<0.05)$. A similar result $(6.43)$ was found by Yunes (2010) in his study with a pork product emulsified soon after preparation. The same study emphasized

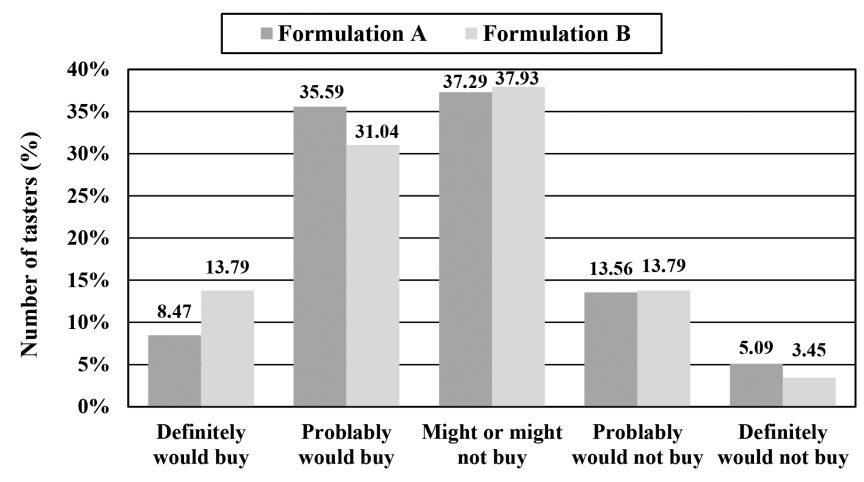

Figure 3. Purchase intention of tasters with regard to formulations $\mathrm{A}$ and $\mathrm{B}$.

Table 2. Results for $\mathrm{pH}$, proximate composition and caloric value of meatloaves with a comparison of means by the Tukey test at a $5 \%$ error level.

\begin{tabular}{|c|c|c|c|c|}
\hline \multirow{2}{*}{$\begin{array}{l}\text { Determinations } \\
(\mathrm{g} / 100 \mathrm{~g})\end{array}$} & \multicolumn{4}{|c|}{ Meatloaf (Mean and Standard Deviation) ${ }^{\mathrm{a}}$} \\
\hline & Standard & Formulation A & Formulation B & $\operatorname{LSD}^{\mathrm{b}}(5 \%)$ \\
\hline $\mathrm{pH}$ & $6.46(0.02)^{2}$ & $6.39(0.02)^{3}$ & $6.53(0.02)^{1}$ & 0.021 \\
\hline Moisture and volatile matter & $59.32(0.11)^{2}$ & $59.46(0.17)^{2}$ & $60.71(0.05)^{1}$ & 0.296 \\
\hline Ash content & $1.76(0.02)^{3}$ & $2.67(0.01)^{2}$ & $3.46(0.06)^{1}$ & 0.085 \\
\hline Protein $(\mathrm{N} x 6.25)$ & $14.54(0.25)^{3}$ & $18.14(0.07)^{2}$ & $19.13(0.13)^{1}$ & 0.425 \\
\hline Lipids & $24.38(0.14)^{1}$ & $19.74(0.14)^{2}$ & $16.71(0.16)^{3}$ & 0.366 \\
\hline Caloric valuec & $277.59(0.32)^{1}$ & $250.21(1.34)^{2}$ & $226.87(0.94)^{3}$ & 2.407 \\
\hline
\end{tabular}

${ }^{a}$ mean of 3 repetitions. ${ }^{b} L S D$ : least significant difference for the Tukey test at a $5 \%$ error level. ${ }^{c}$ caloric value $\left(\mathrm{kcal}^{\mathrm{a}} 100 \mathrm{~g}^{-1}\right)=($ lipids $\mathrm{x} 9)+($ proteins $\mathrm{x} 4)+($ carbohydrates $\mathrm{x} 4)$. Mean values (mean and standard deviation) followed by the same number are not statistically different.

Table 3. Results for the determination of mineral elements in meatloaves with a comparison of means by the Tukey test at a $5 \%$ error level.

\begin{tabular}{|c|c|c|c|c|}
\hline \multirow{2}{*}{$\begin{array}{l}\text { Mineral elements } \\
(\mathrm{mg} / 100 \mathrm{~g})\end{array}$} & \multicolumn{4}{|c|}{ Samples of meatloaf (Mean and Standard Deviation) } \\
\hline & Standard & Formulation A & Formulation B & $\operatorname{LSD}^{\mathrm{a}}(5 \%)$ \\
\hline Calcium & $5.30(0.21)^{2}$ & $8.58(0.34)^{1}$ & $9.42(0.47)^{1}$ & 0.890 \\
\hline Copper & $0.025(0.003)^{3}$ & $0.11(0.009)^{2}$ & $0.21(0.03)^{1}$ & 0.046 \\
\hline Iron & $1.65(0.04)^{3}$ & $3.30(0.08)^{2}$ & $4.17(0.04)^{1}$ & 0.143 \\
\hline Phosphorus & $137.55(1.61)^{3}$ & $268.56(6.54)^{2}$ & $294.48(5.53)^{1}$ & 12.610 \\
\hline Sodium & $874.70(5.11)^{1}$ & $889.41(6.27)^{1}$ & $888.82(2.08)^{1}$ & 1.690 \\
\hline Magnesium & $12.34(0.41)^{2}$ & $18.03(0.33)^{1}$ & $18.62(0.19)^{1}$ & 0.802 \\
\hline Zinc & $1.92(0.09)^{3}$ & $3.28(0.07)^{2}$ & $3.80(0.03)^{1}$ & 0.176 \\
\hline
\end{tabular}

${ }^{a}$ LSD $(5 \%)=$ least significant difference of Tukey test at a $5 \%$ error level. Means followed by the same number are not statistically different.

Table 4. Results for acceptance test of meatloaves prepared with formulations A and B with a comparison of means by the Tukey test at a $5 \%$ error level.

\begin{tabular}{cccc}
\hline Attributes & Formulation A & Formulation B & LSD $^{\mathrm{a}}(5 \%)$ \\
\hline Appearance & $6.37(1.40)^{1}$ & $6.17(1.40)^{1}$ & 0.27 \\
Color & $6.72(1.19)^{1}$ & $6.47(1.33)^{1}$ & 0.26 \\
Odor & $6.48(1.42)^{1}$ & $6.30(1.52)^{1}$ & 0.31 \\
Taste & $6.85(1.54)^{1}$ & $7.13(1.35)^{1}$ & 0.39 \\
Texture & $7.05(1.43)^{1}$ & $6.83(1.32)^{1}$ & 0.38 \\
\hline
\end{tabular}

${ }^{a} \mathrm{LSD}=$ least significant difference at a $5 \%$ error level. Means in the same line followed by the same number are not statistically different. 
that the $\mathrm{pH}$ value of the product decreased over time due to a number of factors, such as the growth of lactic bacteria and the consequent production of acids throughout the storage period. Meatloaves with $\mathrm{pH}$ above 6 are characterized as a perishable product, therefore they are recommended to be stored using a vacuum-packaging system or under modified atmosphere (Bressan et al., 2007).

Moisture levels reached $59.32 \%$ in the standard formulation, $59.46 \%$ in formulation $\mathrm{A}$, and $59.61 \%$ in formulation B, with statistically significant differences between formulation $B$ and the other two formulations, but no significant difference between standard formulation and formulation A ( $p>0.05)$. Since there is no technical regulation for the product under analysis, comparisons were performed using the technical regulation of identity and quality for emulsified meat products such as mortadella and sausage, which are the most similar to meatloaf in terms of composition (Brasil, 2000). These products have an upper limit of $65 \%$ for moisture, according to the technical regulation of identity and quality for mortadella issued by the Brazilian Ministry of Agriculture, Livestock, and Supply (Brasil, 2000). It can be observed that the data obtained were in agreement with those reported by Yunes (2010) for an emulsified pork meat product $(58.23 \% \pm 0.82)$. Conversely, Fontes (2006) found moisture levels ranging from $64 \%$ to $66 \%$ in mortadellas formulated with different concentrations of blood. Ferreira et al. (2009) observed moisture levels between $63 \%$ and $67 \%$ in sausages prepared with reduced fat content and added with whey protein concentrate. These results showed higher values than those from the present study, which is probably a consequence of the baking process to which meatloaf is subjected. Therefore, it is observed that, when it comes to moisture, the different formulations of meatloaf are in agreement with the technical regulation of identity and quality for the above mentioned emulsified meat products.

The values obtained for ash content were $1.76 \%$ for the standard formulation, $2.67 \%$ for formulation $\mathrm{A}$, and $3.46 \%$ for formulation B. Tukey test showed that there were statistical differences between these values $(\mathrm{p}<0.05)$. The increase in the ash content was probably due to the presence of pork liver in the formulations A and B, since it is known that liver is characterized as an excellent source of minerals, especially iron. Thus, with the addition of liver in the formulations probably there was an increase of minerals resulting in an increase of ash content. The results obtained point to this fact as it has been some correspondence between the increase of iron content and other minerals with the increase of liver in the formulation, consequently leading to an increase of ash content. Estévez et al. (2005) found an ash content between $1.06 \mathrm{~g}$ and $2.73 \mathrm{~g} / 100 \mathrm{~g}$ in meat products prepared with pork liver. These authors also emphasized that the presence of pork liver in the formulation leads the product to have iron levels higher than those usually found in traditional meat products and in fortified foods.

The results for protein concentration were $14.54 \%, 18.14 \%$, and $19.13 \%$ for the standard formulation and for formulations $\mathrm{A}$ and B, respectively. These results were significantly different among themselves $(\mathrm{p}<0.05)$ and are in agreement with the technical regulation of identity and quality for mortadella, which establishes $12 \%$ as the lower limit of protein (Brasil, 2000).
The higher protein content observed in formulations A and B compared to the standard formulation may be explained by the addition of pork liver to these formulations at percentages of $9.98 \%$ and $13.31 \%$. Similar results were found by Ferreira et al. (2009), who used fat substitutes based on non-meat protein (with lower inclusion of fat) in sausages and found protein values ranging from $17.5 \%$ to $20.8 \%$. In his study with mortadellas, Fontes (2006) found mean protein levels of $16.45 \%$, with a standard deviation of $0.66 \%$. Therefore, the higher protein content found in formulations A and B shows how important meatloaf is when intended to be used to feed preschool children, since proteins are important for children's growth and intellectual development, especially those of animal origin, because they are complete and have a better balance of essential amino acids and a higher rate of digestibility when compared to proteins of vegetable origin.

The results for fat content were $24.38 \%, 19.74 \%$, and $16.71 \%$ for the standard formulation and for formulations $\mathrm{A}$ and $\mathrm{B}$, respectively. These results were significantly different among themselves $(p<0.05)$ and are in agreement with the technical regulation of identity and quality for mortadella, which establishes $30 \%$ as the upper limit for total fat content (Brasil, 2000). It was observed that formulations A and B had a reduction in fat content equivalent to $19 \%$ and $31.5 \%$ compared to the standard formulation. A product to be classified as light should have a reduction of at least $25 \%$ in calories or in a given nutrient (Brasil, 1998), thus formulation B can be classified as a product light in fat.

In turn, the fat content in formulation B $(16.71 \%)$ was similar to the fat percentage $(16.19 \% \pm 2.28)$ obtained by Yunes $(2010)$ with an emulsified pork meat product. Conversely, the reduction in fat content is considered a positive finding, because obesity has become a public health problem even among children.

It should be noted that moisture, protein, and fat, in addition to being nutritionally important, also have an influence on important quality parameters such as color, flavor, texture, gelation capacity and emulsification.

Caloric values of meatloaves were 277.59, 250.21, and $226.87 \mathrm{kcal} 100 \mathrm{~g}^{-1}$ for the standard formulation and formulations $A$ and $B$ respectively, were significantly different $(p<0.05)$, and were close to the values found by Ferreira et al. (2009) in sausages with reduced fat content (191.93 to $\left.269.43 \mathrm{kcal} 100 \mathrm{~g}^{-1}\right)$. When the caloric values of formulations $\mathrm{A}$ and $\mathrm{B}$ were compared to that of the standard formulation, a reduction of $9.86 \%$ and $18.27 \%$ respectively was observed. This reduction, which results from the lower fat content, is a positive point in favor of formulations $\mathrm{A}$ and $\mathrm{B}$, due to the high incidence of overweight and obesity in preschool children (Estévez et al., 2005).

Meat is an important source of minerals. However, most meat products contain ingredients other than meat, which leads to changes in mineral profile, so that different products have different mineral profiles based on their formulations (ingredients). Some minerals have metabolic functions and thus affect individual's physical and mental performance. Data obtained in this study (Table 3) reveal that there was an increase in the level of all minerals in formulations A and B compared to the standard formulation, with statistically significant differences, exception for sodium. 
When comparing mineral levels of formulations A and B, it was observed that differences were not significant for calcium (Ca), sodium (Na), and magnesium ( $\mathrm{mg}$ ), but were significant for copper $(\mathrm{Cu})$, iron $(\mathrm{Fe})$, phosphorus $(\mathrm{P})$, and zinc $(\mathrm{Zn})$.

The iron content in formulations A $(3.30 \mathrm{mg} / 100 \mathrm{~g})$ and B $(4.17 \mathrm{mg} / 100 \mathrm{~g})$ was respectively $100.0 \%$ and $152.73 \%$ higher than that of the standard formulation ( $1.65 \mathrm{mg} \mathrm{Fe} / 100 \mathrm{~g})$ due to addition of pork liver in formulations $\mathrm{A}$ and $\mathrm{B}$. These values are also higher than those obtained by Jiménez-Colmenero et al. (2010), who found an iron content of $1.44 \mathrm{mg} \mathrm{Fe} / 100 \mathrm{~g}$ in "chorizo" (type of salami), $0.79 \mathrm{mg} \mathrm{Fe} / 100 \mathrm{~g}$ in "longaniza” (fresh sausage), and $0.59 \mathrm{mg} \mathrm{Fe} / 100 \mathrm{~g}$ in "lomosajonia" (baked smoked pork leg). Conversely, Dalmás et al. (2011) found an iron content of 6.48, 7.92 , and $9.99 \mathrm{mg} \mathrm{Fe} / 100 \mathrm{~g}$ in 3 types of pâté made with goat liver, blood and meat respectively, values two to three times as high as those obtained in the present study, which may be explained by the presence of blood in pâté formulations.

Taking into consideration that the daily iron needs of preschool children is $10 \mathrm{mg} /$ day (Institute of Medicine, 2002) and that the mean intake of meatloaf is $50 \mathrm{~g}$ per child, the formulations developed in this study (A and B) would meet $16.5 \%$ and $20.8 \%$ of daily needs respectively. Therefore, meatloaves prepared with formulations A and B may be considered good sources of iron and good options of meat product to be used in school meals with the purpose of reducing the incidence of iron deficiency anemia.

Zinc contributes to several biochemical functions, since it is present in more than 200 enzymes, including those of the central nervous system. This mineral acts in cell division, genetic expression, and in physiological processes of growth and development (Fidelis \& Osório, 2007). The values for zinc content found in this study for formulations A (3.28 mg/100g) and B (3.80 mg/100g) were higher than those found by Jiménez-Colmenero et al. (2010) and Dalmás et al. (2011).

Considering that the daily zinc needs of preschool children is $10 \mathrm{mg} /$ day (Institute of Medicine, 2002) and that the mean intake of meatloaf is $50 \mathrm{~g}$ per child, the formulations developed in this study (A and B) would meet $16.4 \%$ and $19.0 \%$ of daily needs respectively. Therefore, meatlaoves prepared with formulations $\mathrm{A}$ and $\mathrm{B}$ may also be considered good sources of zinc, providing $15 \%$ to $20 \%$ of children's daily needs.

Thus, it can be concluded that both formulations comply with the specifications of the Brazilian National School Meal Program (Programa Nacional de Alimentação Escolar, PNAE) (Brasil, 2013), because the intake of $50 \mathrm{~g}$ of meatloaf in a meal will supply more than $15 \%$ of daily needs of iron and zinc.

It was observed that magnesium levels in formulations $\mathrm{A}$ (18.03 mg/100g) and B (18.62 mg/100g) were very close to those found by Jiménez-Colmenero et al. (2010) and Dalmás et al. (2011).

With regard to sodium, its values result from the sodium chloride used in the formulation, which means that each formulation represents a specific case. In Brazil, sodium intake has always been above the recommended needs and is part of Brazilians'eating habits. Although it is currently known that excessive sodium intake represents a problem, reversing this trend has not been an easy task, given the influence of salt on the flavor of foods. However, there is a current trend to reduce its consumption due to its interference with chronic degenerative diseases.

As for copper, a heavy metal, it is considered toxic when found in an amount higher than the maximum intake limit established by public health bodies, because it may cause severe neurological problems, gastric disorders, and many other symptoms. Data presented by Tomovića et al. (2011) in turn, showed that mean copper content in pork liver was 5 times as high as that found in pork meat ( 1.61 vs. $0.32 \mathrm{mg}$ of $\mathrm{Cu} / 100 \mathrm{~g}$ ). Therefore, an increase in the amount of liver in the formulation leads to an increase in copper levels in the product, whose maximum level allowed by legislation is 3ppm (Brasil, 1998). Cooper levels presented in Table 3 confirm this fact, since they indicate that the increase in cooper content was proportional to the amount of liver used in the formulation. Cooper values found in formulations $A$ $(0.11 \mathrm{mg} / 100 \mathrm{~g})$ and $\mathrm{B}(0.21 \mathrm{mg} / 100 \mathrm{~g})$ were statistically significant and were below the upper limit of $3 \mathrm{ppm}$ (equivalent to $0.3 \mathrm{mg}$ of $\mathrm{Cu} / 100 \mathrm{~g}$ ) established by legislation.

Phosphorus content in pork liver is $375 \mathrm{mg} / 100 \mathrm{~g}$, which is considered a high value compared to pork meat $(227 \mathrm{mg} / 100 \mathrm{~g})$. Thus, products added with liver may have a higher phosphorus content than products without liver. For this reason, the phosphorus content in formulations $\mathrm{A}(268.56 \mathrm{mg} / 100 \mathrm{~g})$ and $\mathrm{B}$ (294.48mg/100g) was high, being $7.9 \%$ and $18.3 \%$ higher than the value found by Dalmás et al. (2011) (249mg/100g).

Finally, calcium levels were close to the values presented by other authors (Dalmás et al., 2011; Jiménez-Colmenero et al., 2010).

From the microbial point of view meatloaves prepared with pork liver were considered to be adequate for consumption since the results from the microbiological analyses for Clostridium sulphite reducer, Salmonella ssp, Staphylococcus aureus, Coliforms at $45^{\circ} \mathrm{C}$, and total and fecal coliforms. were below limit values established by the Brazilian legislation (Resolution no. 12/01) (Brasil, 2001). By enabling the final temperature of the geometric center of the product to reach $75^{\circ} \mathrm{C}$, baking showed to be efficient in microbial control, leading the recently prepared product to have low bacterial counts that do not pose any health risk for the consumer.

Therefore, although no considerable levels of microorganisms were found in this study, the literature points out that food contamination is a worldwide reality. Issues such as food manipulation and conservation are relevant, as well as crosscontamination between raw and processed products; however, these issues are not taken as seriously as they should by food manipulators (Welker et al., 2010).

Data from Table 4 reveal that the values obtained for samples A (9.98\% of pork liver) and B (13.31\% of pork liver) in terms of appearance, color, odor, flavor and texture were not statistically different between each other. It can be observed that means for formulation A ranged from 6.37 to 7.05 , while those for formulation $B$ ranged from 6.17 to 7.13 . The attribute appearance showed the lowest mean in both formulations, followed by odor and color. On the other hand flavor and texture achieved the highest means. According to the hedonic scale used in this study, as stated by 
Beserra et al. (2003), scores between 6 and 9, corresponding to "Liked it slightly" and "Like it extremely" respectively, suggest that the product may be accepted in the consumer market from a sensory point of view. Taking this assumption into account, both formulations present favorable market conditions.

As for the attribute color, although no significant difference was found between formulations $\mathrm{A}$ e $\mathrm{B}$, when these formulations were compared with the standard formulation it could be observed that the presence of pork liver led to the darkening of the product. Some tasters remarked that they did not like the appearance of samples of formulation B, which could be ascertained by the fact that these samples showed lower mean for appearance, although the difference was not statistically significant at a 5\% significance level. Additionally, some tasters classified meatloaves as spicy, salty, and dry, and associated them with cold cuts and hamburgers.

When evaluating the acceptance of rabbit hamburgers, Tavares et al. (2007) obtained mean values of 5.85 in a sevenpoint scale, which was considered an excellent acceptance by the authors. Furthermore, rabbit hamburgers were considered good by the tasters in terms of color $(89.29 \%)$, flavor $(78.57 \%)$, odor (81.55\%), and texture (81.55\%). Beserra et al. (2003) developed a ham-like cooked product containing different levels of meat from culled goats and sows and obtained lower means, which ranged from 4.44 to 6.06 for appearance, 3.42 to 6.08 for flavor, 4.30 to 6.50 for taste, 4.22 to 6.32 for texture, and 4.10 to 6.88 for overall acceptability. Based on the results obtained, the authors found that the product containing $75 \%$ pork and $25 \%$ goat meat was the one that showed the best overall acceptability. Hautrive et al. (2008), in turn, analyzed three hamburger formulations, one with bovine meet, other with ostrich meat, and other with both types of meat (mixed), and concluded that the last one obtained better acceptance than the others, with mean values of $6.84,6.90,7.62$, and 7.8 for appearance, color, taste, and texture respectively, with higher values than those obtained in the present study.

Results similar to this study were obtained by Ferreira et al. (2009) when evaluating pork sausages with reduced fat content added with different levels of protein concentrates on the first and the seventh day after preparation. Mean scores for overall palatability ranged, respectively, from 6.03 to 6.27 and from 6.23 to 6.41 at first and seventh days. These results also showed that there was no significant difference between the different meat treatments. François et al. (2009) obtained fermented sausage of the salami type using different proportions of meat from culled ewes and sows and found that the addition of $15 \%$ of sheep meat in the formulation improved the characteristics evaluated in the study, such as color, odor, taste, and texture, compared to standard salami, and that satisfactory results could also be achieved with the addition of up to $75 \%$ of sheep meat.

The analysis of data from Figure 3 shows that formulations $A$ and B showed very similar results. Thus, the sum of the two first items ("definitely would buy it" and "probably would but it") was $44.06 \%$ and $44.83 \%$ for formulations A and B, respectively. When a third item is considered ("might or might not buy it"), these values were $81.35 \%$ and $82.76 \%$. Although these percentages are very close between each other, the main difference was found in the most important item ("definitely would buy it"), in which formulation B showed better acceptance (13.79\% vs. 8.47\% for formulation A).

Higher values than those obtained in this study were found by Tavares et al. (2007), who assessed the purchase intention of rabbit hamburgers using a closed "yes" and "no" question and found a $92.26 \%$ of purchase intention among tasters. A similar test was performed by Hautrive et al. (2008) with hamburgers prepared with ostrich meat, bovine meat, and both meats (mixed) also using a closed "yes" and "no" question on purchase intention of the hamburger tasters liked the most, obtaining $94 \%$ of approval from tasters.

\section{Conclusion}

The presence of pork liver, a meat by-product, in the meatloaf increased the levels of protein and mineral matter and reduced the levels of fats, with more pronounced changes in formulation $B$. There was an increase in the minerals evaluated in this study, especially iron and zinc, with increases of $100.0 \%$ and $152.73 \%$ for iron and $70.83 \%$ and $97.92 \%$ for zinc in formulations $\mathrm{A}$ and $\mathrm{B}$, respectively. With regard to sensory analysis, the attributes appearance, color, odor, taste, and texture were not statistically different between formulations A and B. However, formulation $\mathrm{B}$ showed better acceptance in the purchase intention test.

Therefore, formulations A and B can be considered as good sources of iron and zinc, supplying 15 and $20 \%$ of the daily needs of these minerals for preschool children, being a viable option to reduce the incidence of iron deficiency anemia. Hence, meatloaves prepared with formulations A and B showed to be appropriate for use in the Brazilian National School Meal Program. Furthermore the meatloaves can be considered convenience product being ready for use after their thawing and heating.

\section{References}

Assis, A. M., Gaudenzi, E. N., Gomes, G., Ribeiro, R. C., Szarfarc, S. C., \& Souza, S. B. (2004). Hemoglobin concentration, breastfeeding and complementary feeding in the first year of life. Revista de Saúde Pública, 38(4), 543-551. http://dx.doi.org/10.1590/S003489102004000400010. PMid:15311295.

Bach Kristensen, M., Hels, O., Morberg, C., Marving, J., Bügel, S., \& Tetens, I. (2005). Pork meat increases iron absorption from a 5-day fully controlled diet when compared to a vegetarian diet with similar vitamin C and phytic acid content. British Journal of Nutrition, 94(1), 78-83. http://dx.doi.org/10.1079/BJN20051417. PMid:16115336.

Baech, S. B., Hansen, M., Bukhave, K., Jensen, M., Sørensen, S. S., Kristensen, L., Purslow, P. P., Skibsted, L. H., \& Sandström, B. (2003). Nonheme-iron absorption from a phytate-rich meal is increased by the addition of small amounts of pork meat. The American Journal of Clinical Nutrition, 77(1), 173-179. PMid:12499338.

Beinner, M. A., \& Lamounier, J. A. (2003). Recent experience with fortification of foods and beverages with iron for the control of iron-deficiency anemia in Brazilian children. Food and Nutrition Bulletin, 24(3), 268-274. PMid:14564931.

Beserra, F. J., Melo, L. R. R., Rodrigues, M. C. P., Silva, E. M. C., \& Nassu, R. T. (2003). Desenvolvimento e caracterização físico-química e sensorial de embutido cozido tipo apresuntado de carne de caprino. 
Ciência Rural, 33(6), 1141-1147. http://dx.doi.org/10.1590/S010384782003000600022.

Brasil, Ministério da Saúde. (1998, January 16). Aprova o regulamento técnico referente a alimentos adicionados de nutrientes essenciais (Portaria $n^{\circ}$ 31, de 13 de janeiro de 1998). Diário Oficial [da] República Federativa do Brasil. Retrieved from http://portal.anvisa. gov.br/wps/wcm/connect/6d074500474583c18ed7 de3fbc4c6735/ PORTARIA+_31_1998.pdf?MOD=AJPERES

Brasil, Ministério da Agricultura e do Abastecimento. (2000, April 05). Regulamento técnico para fixação de identidade e qualidade de carne mecanicamente separada (CMS) de aves, bovinos e suínos (Instrução Normativa no ${ }^{\circ}$, de 31 de março de 2000). Diário Oficial [da] República Federativa do Brasil. Retrieved from http:// extranet.agricultura.gov.br/sislegis-consulta/consultarLegislacao. do? operacao $=$ visualizar $\&$ id $=7778$

Brasil, Ministério da Saúde. Agência Nacional de Vigilância Sanitária. (2001, January 10). Dispõe sobre o regulamento técnico sobre padrões microbiológicos para alimentos (Resolução - RDC no 12 , de 02 de janeiro de 2001). Diário Oficial [da] República Federativa do Brasil. Retrieved from http://bvsms.saude.gov.br/bvs/ saudelegis/ anvisa/2001/res0012_02_01_2001.html

Brasil, Ministério da Saúde. (2009). Compromisso social para redução da anemia por carência de ferro no Brasil. Diário Oficial [da] República Federativa do Brasil. Retrieved from http://bvsms.saude.gov.br/bvs/ publicacoes/compromisso_social.pdf

Brasil, Ministério da Educação. Fundo Nacional de Desenvolvimento da Educação - FNDE (2013). Alimentação Escolar (Resolução n ${ }^{\circ}$ 26, de 17 de junho de 2013). Diário Oficial [da] República Federativa do Brasil. Retrieved from http://www.fnde.gov.br

Bressan, M. C., Lodi, F., Ferreira, M. W., Andrade, P. L., Boari, C. A., \& Piccoli, R. H. (2007). Influência da embalagem na vida útil de presuntos fatiados. Ciência e Agrotecnologia, 31(2), 433-438. http:// dx.doi.org/10.1590/S1413-70542007000200025.

Cook, J. D., \& Reusser, M. E. (1983). Iron fortification: an update. The American Journal of Clinical Nutrition, 38(4), 648-659. PMid:6624707.

Dalmás, P. S., Bezerra, T. K. A., Morgano, M. A., Milani, R. F., \& Madruga, M. S. (2011). Development of goat patê prepared with 'variety meat'. Small Ruminant Research, 98(1-3), 46-50. http:// dx.doi.org/10.1016/j.smallrumres.2011.03.016.

Estévez, M., Ventanas, J., Cava, R., \& Puolanne, E. (2005). Characterisation of a traditional Finnish liver sausage and different types of Spanish liver pâtés: A comparative study. Meat Science, 71(4), 657-669. http://dx.doi.org/10.1016/j.meatsci.2005.05.018. PMid:22061211.

Ferreira, A. C. B., Fonseca, L. M., \& Santos, W. L. M. (2009). Composição centesimal e aceitação de lingüiça elaborada com reduzido teor de gordura e adicionada de concentrados protéicos de soro de leite. Ciência Rural, 39(1), 209-214. http://dx.doi.org/10.1590/S010384782009000100032.

Fidelis, C. M. F., \& Osório, M. M. (2007). Consumo alimentar de macro e micronutrientes de crianças menores de cinco anos no Estado de Pernambuco, Brasil. Revista Brasileira de Saúde Materno Infantil, 7(1), 63-74. http://dx.doi.org/10.1590/S1519-38292007000100008.

Fontes, P. R. (2006). Valor protéico, Biodisponibilidade de Ferro e aspectos toxicológicos de mortadelas formuladas com sangue tratado com monóxido de carbono (Tese de doutorado). Universidade Federal de Viçosa, Viçosa.

François, P., Pires, C. C., Griebler, L., François, T., Soriano, V. S., \& Galvani, D. B. (2009). Propriedades físico-químicas e sensoriais de embutidos fermentados formulados com diferentes proporções de carne suína e de ovelhas de descarte. Ciência Rural, 39(9), 2584-2589. http://dx.doi.org/10.1590/S0103-84782009000900031.
Hautrive, T. P., Oliveira, V. R. d., Silva, A. R. D. d., Terra, N. N., \& Campagnol, P. C. B. (2008). Análise físico-química e sensorial de hambúrguer elaborado com carne de avestruz. Ciência e tecnologia de alimentos, 28, 95-101.

Horwitz, W. E. (2010). Official methods of analysis of the Association of Official Analytical Chemists (18th ed.). Gaithersburg: AOAC.

Hurrell, R. F. (2002). Fortification: overcoming technical and practical barriers. The Journal of Nutrition, 132(4, Suppl), 806S-812S. PMid:11925486.

Idjradinata, P., Watkins, W. E., \& Pollitt, E. (1994). Adverse effect of iron supplementation on weight gain of iron-replete young children. Lancet, 343(8908), 1252-1254. http://dx.doi.org/10.1016/S01406736(94)92151-2. PMid:7910275.

Institute of Medicine - IOM. (2002). Dietary Reference Intakes for vitamin $a$, vitamin $k$, arsenic, boron, chromium, copper, iodine, iron, manganese, molybdenum, nickel, silicon, vanadium, and zinc. Washington: National Academy Press.

Instituto Adolfo Lutz - IAL. (2008). Normas analiticas do instituto adolfo lutz (5. ed.). São Paulo.

Jiménez-Colmenero, F., Pintado, T., Cofrades, S., Ruiz-Capillas, C., \& Bastida, S. (2010). Production variations of nutritional composition of commercial meat products. Food Research International, 43(10), 2378-2384. http://dx.doi.org/10.1016/j.foodres.2010.09.009.

Lind, T., Seswandhana, R., Persson, L. A., \& Lönnerdal, B. (2008). Iron supplementation of iron-replete Indonesian infants is associated with reduced weight-for-age. Acta Paediatrica, 97(6), 770-775. http:// dx.doi.org/10.1111/j.1651-2227.2008.00773.x. PMid:18422809.

Lynch, S. R. (2005). The impact of iron fortification on nutritional anaemia. Best Practice \& Research. Clinical Haematology, 18(2), 333346. http://dx.doi.org/10.1016/j.beha.2004.09.003. PMid:15737894.

McClung, J. P., \& Karl, J. P. (2009). Iron deficiency and obesity: the contribution of inflammation and diminished iron absorption. Nutrition Reviews, 67(2), 100-104. http://dx.doi.org/10.1111/j.17534887.2008.00145.x. PMid:19178651.

Muñoz, C., Rios, E., Olivos, J., Brunser, O., \& Olivares, M. (2007). Iron, copper and immunocompetence. British Journal of Nutrition, 98(Suppl 1), S24-S28. http://dx.doi.org/10.1017/S0007114507833046. PMid:17922954.

Silva, N. J. V. C. A., Silveira, N. F. A., Taniwaki, M. H., Santos, R. F. S. \& Gomes, R. A. R. (2010). Manual de métodos de análise microbiológica de alimentos e água (4. ed.). São Paulo: Livraria Varela.

Statsoft. (2000). Statistica for Windows. Tulsa. Computer Program Manual. Retrieved from http://www.statsoft.com.

Tavares, R. S., Cruz, A. G., Oliveira, T. S., Braga, A. R., Reis, F. A., Hora, I. M. C., Teixeira, R. C., \& Ferreira, E. F. (2007). Processamento e aceitação sensorial do hambúrguer de coelho (Orytolagus cunicullus). Food Science and Technology, 27(3), 633-636. http:// dx.doi.org/10.1590/S0101-20612007000300031.

Tomovića, V. M., Petrovića, L. S., Tomovićb, M. S., Kevrešanc, Ž. S., \& Džinića, N. R. (2011). Determination of mineral contents of semimembranosus muscle and liver from pure and crossbred pigs in Vojvodina (northern Serbia). Food chemestry, 124, 342-348.

Welker, C. A. D., Both, J. M. C., Longaray, S. M., Haas, S., Soeiro, M. L. T., \& Ramos, R. C. (2010). Análise microbiológica dos alimentos envolvidos em surtos de doenças transmitidas por alimentos (DTA) ocorridos no estado do Rio Grande do Sul, Brasil. Revista Brasileira de Biociências, 8, 44-48.

Yunes, J. F. F. (2010). Avaliação dos efeitos da adição de óleos vegetais como substitutos de gordura animal em mortadela (Master's Dissertation). Universidade Federal de Santa Maria, Santa Maria. 